\title{
Comparison of the Resistance to Bending Forces of the 4.5 LCP Plate-rod Construct and of 4.5 LCP Alone Applied to Segmental Femoral Defects in Miniature Pigs
}

\author{
Lucie Urbanová ${ }^{1}$, Robert Srnec ${ }^{1}$, Pavel Proks ${ }^{2}$, Ladislav Stehlík ${ }^{2}$, Zdeněk Florian ${ }^{3}$, \\ Tomáš Návrat ${ }^{3}$, Alois Nečas ${ }^{1}$ \\ ${ }^{1}$ Department of Surgery and Orthopaedics, Small Animal Clinic, Faculty of Veterinary Medicine, \\ University of Veterinary and Pharmaceutical Sciences, Brno, Czech Republic \\ ${ }^{2}$ Department of Diagnostic Imaging, Small Animal Clinic, Faculty of Veterinary Medicine, \\ University of Veterinary and Pharmaceutical Sciences, Brno, Czech Republic \\ ${ }^{3}$ Institute of Solid Mechanics, Mechatronics and Biomechanics \\ Faculty of Mechanical Engineering, University of Technology Brno, Czech Republic
}

Received October 26, 2010

Accepted November 24, 2010

\begin{abstract}
The study deals with the determination of mechanical properties, namely resistance to bending forces, of flexible buttress osteosynthesis using two different bone-implant constructs stabilizing experimental segmental femoral bone defects (segmental ostectomy) in a miniature pig ex vivo model using $4.5 \mathrm{~mm}$ titanium LCP and a $3 \mathrm{~mm}$ intramedullary pin ("plate and rod" construct) (PR-LCP), versus the $4.5 \mathrm{~mm}$ titanium LCP alone (A-LCP). The "plate and rod" fixation (PR-LCP) of the segmental femoral defect is significantly more resistant $(p<0.05)$ to bending forces $(200 \mathrm{~N}, 300 \mathrm{~N}$, and $500 \mathrm{~N})$ than LCP alone (A-LCP). Stabilisation of experimental segmental lesions of the femoral diaphysis in miniature pigs by flexible bridging osteosynthesis $4.5 \mathrm{~mm}$ LCP in combination with the "plate and rod" construct appears to be a suitable fixation of non-reducible fractures where considerable strain of the implants by bending forces can be assumed. These findings will be used in upcoming in vivo experiments in the miniature pig to investigate bone defect healing after transplantation of mesenchymal stem cells in combination with biocompatible scaffolds.
\end{abstract}

Fracture fixation, comminuted fracture, ostectomy, buttress osteosynthesis, implant failure

In connection with fracture fixation all long bones are strained, especially by bending forces because the forces that strain the bones act eccentrically towards the centre of the bone. If the bone is exposed to these forces, these bending forces produce compression on the concave surface of the bone and tension on the convex side of the bone. Selection of the technique of fixation of the fracture should prevent, above all, the undesirable forces because they are the most frequent cause of failure of the fixation and cause dislocation of bone fragments and a collapse of the line of the fracture (Hulse et al 2005).

Critically sized bone defects in the form of comminuted fractures, and ostectomies after excision of bone tumours can be imitated by experimental removal of a larger bone column (segmental ostectomy) (Nečas et al. 2010a,b). For the stabilization of these bone defects (if anatomical reduction is not possible) due to the loss of continuity of the bone column, bridging osteosynthesis is usually used (Piermattei and Flo 1997; Koch 2005; Nečas et al. 2007). In this bridging type of fixation, the loading forces are transferred through the implant until a bone callus is formed, and bone nonunion remains a problem both in human and veterinary medicine (Lambiris et al. 2007). It is presumed that healing of the bone defect may be supported by transplantation of mesenchymal stem cells in combination with biomaterial scaffolds (Crha 2009; Nečas et al. 2009), similar to the healing of physeal defects and articular cartilage lesions (Jančář et al. 2007; Koláčná et al. 2007; Krupa et al. 2007; Plánka et al. 2007; Varga et al. 2007; Míčková et al. 2008; Nečas et al. 2008; Planka et al. 2008; Jančář et al. 2009; Nečas et al. 2009; Plánka et al. 2009a,b; Nečas et al. 2010).

Address for correspondence:

MVDr. Lucie Urbanová

Department of Surgery and Orthopaedics

Small Animal Clinic, Faculty of Veterinary Medicine

University of Veterinary and Pharmaceutical Sciences Brno

Palackého 1-3, 61242 Brno, Czech Republic
Phone: +420 541562349

Fax: +420 541562344

E-mail: lucieurbanova@email.cz

http://www.vfu.cz/acta-vet/actavet.htm 
When evaluating the primary clinical results of the in vivo experimental study focused on the healing of bone lesions (project NPV II 2B06130) it was found that the five-hole titanium $4.5 \mathrm{~mm}$ LCP ("Locking Compression Plate") appears to be a more suitable implant than the six-hole $3.5 \mathrm{~mm}$ LCP for flexible buttress osteosynthesis of a large segmental defect of the femoral diaphysis of a miniature pig as an experimental animal model (Nečas et al. 2010a). The results of the present study will help to reduce undesirable failure of the implants in time-consuming and costly transplantation experiments focused on bone healing. Nevertheless, even in the case of the more rigid $4.5 \mathrm{~mm}$ system of LCP undesirable failure of the fixation was seen in some animals in an in vivo study; i.e. the breaking of the $4.5 \mathrm{~mm}$ titanium LCP (Nečas et al. 2010a). Yet the rigidity of the fixation could be increased more, for instance by using the "plate and rod" technique. The "plate and rod" technique is a significantly more rigid type of fixation of fractures than the buttress plate alone. The probability of failure of the plate alone is ten times higher than in combination with the "plate and rod" fixation (Hulse et al 1997). For this reason we decided to check the mechanical properties of the $4.5 \mathrm{~mm}$ LCP in combination with the intramedullary pin ("plate and rod" technique) and compare it with the buttress $4.5 \mathrm{~mm}$ LCP alone on an ex vivo model before the potential use of this technique for fixation of a large segmental defect of the femoral diaphysis in our experimental model of miniature pig in an in vivo study.

The objective of the study was to compare the mechanical properties in terms of resistance of the fixation to bending forces in two techniques bridging osteosynthesis of the segmental diaphyseal femoral defect using only a five-hole $4.5 \mathrm{~mm}$ titanium LCP (Synthes ${ }^{\mathbb{Q}}$, Switzerland) (model A-LCP) or a five-hole $4.5 \mathrm{~mm}$ titanium LCP $\left(\right.$ Synthes $^{\mathbb{R}}$ ) in combination with the "plate and rod" construct (model PR-LCP). As far as we know testing and comparison of mechanical properties of the bone-implant construct under bending force on flexible bridging osteosynthesis with only $4.5 \mathrm{~mm}$ titanium LCP vs. $4.5 \mathrm{~mm}$ titanium LCP in combination with the "plate and rod" construct in an ex vivo model of segmental ostectomy of the femur in miniature pigs has not yet been studied.

\section{Materials and Methods}

As an ex vivo model for testing the mechanical properties of flexible bridging osteosynthesis of the segmental diaphyseal defect of the femur we selected a construct of the right femur of miniature pigs of comparable age (8-10 months) and size (used in studies of healing of a large segmental defect of the left femur by means of transplantation of mesenchymal stem cells in combination with bio-compatible scaffolds as part of the wider research project NPV II 2B06130). The right (not operated) femurs $(n=5)$ of these miniature pigs were prepared immediately after euthanasia upon termination of clinical monitoring as part of the project NPV II 2B06130, i.e. 16 weeks after transplantation. The prepared femurs were wrapped separately in plastic bags and frozen at $-18^{\circ} \mathrm{C}$. Prior to the testing of the mechanical properties of the flexible bridging osteosynthesis of the segmental diaphyseal femoral defect, the samples of the prepared bones were slowly defrosted during $24 \mathrm{~h}$ in a water bath of a temperature of $25-27^{\circ} \mathrm{C}$.

In the middle of the diaphysis of thus prepared left femur of the miniature pig $(n=5)$, an iatrogenic segmental bone defect (ostectomy) was created using the oscillation saw in the entire cross-section of the bone of a height of $15 \mathrm{~mm}$ of the bone column of the femoral diaphysis. Observing the rules of flexible bridging osteosynthesis (Stoffel et al. 2000; Gautier and Sommer 2003; Stoffel et al. 2003; Wagner 2003) we then performed fixation and stabilisation of the main femoral fragments with the "plate and rod" technique bridging osteosynthesis with a five-hole titanium LCP (Synthes ${ }^{\circledR}$, Switzerland) in the $4.5 \mathrm{~mm}$ system and with four $4.5 \mathrm{~mm}$ titanium locking screws inserted bicortically (leaving central plate hole empty (without screw) at the level of the segmental bone defect) in combination of the "plate and rod" technique with $3 \mathrm{~mm}$ intramedullary Steinmann pin which filled $30 \%$ of the diameter of the bone cavity in its isthmus - model PR-LCP $(n=5)$.

These prepared ex vivo models of bones with implants were handed over to be tested for mechanical properties (bending strain) on the experimental machine ZWICK Z 020-TND. A three-piece metal fixture was made to fasten the tested construct to the experimental machine in the shape of 1) a small square bath $(10 \times 10 \mathrm{~cm})$ with $2 \mathrm{~cm} \mathrm{high}$ walls into which the distal and proximal end of the bone was fixed with poly methyl metacrylate (PMMA) and equipped with a V-groove; 2$)$ square plate $(10 \times 10 \mathrm{~cm}) 0.5 \mathrm{~cm}$ thick equipped with a V-groove enabling fixation of the sample in the arms of the experimental machine ZWICK Z 020-TND; and 3) roller $1.5 \mathrm{~cm}$ in diameter inserted between the V-grooves of both parts of the anchoring element (Plate VIII, Fig. 1) (Urbanová et al. 2010). First of all the ex vivo model of flexible bridging osteosynthesis (PR-LCP) was tested mechanically in such a way that it 
was subjected to bending strain of defined force and the values of mutual displacement of the distal and proximal segments of the osteotomised bone were measured (Plate IX, Fig. 2). Subsequently the intramedullary pin was removed from the construct and the construct of the bone fixed only with LCP (A-LCP) was tested in the same way $(n=5)$. In all the samples we compared the difference in the mutual displacement of fragments $(\mathrm{mm})$ under the action of $200 \mathrm{~N}, 300 \mathrm{~N}$ and $500 \mathrm{~N}$ forces. For statistical evaluations of the results we used the paired Wilcoxon test for two related samples because of the small number of monitoring.

\section{Results}

In all cases a significant difference was found $(p<0.05)$ in the size of the mutual displacement (approximation) of fragments of bones fixed by only LCP as compared to fixations with LCP in combination with the "plate and rod" technique under the action of similar forces $(200 \mathrm{~N}, 300 \mathrm{~N}$ and $500 \mathrm{~N})$ (Tables 1, 2 and 3). The difference in the course

Table 1. Size of mutual displacement of the proximal and distal bone fragment (collapse of the line of the fracture) in $\mathrm{mm}$ $(p=0.02)$ using the "plate and rod" fixation (PR-LCP) and LCP alone (A-LCP) under a force of $200 \mathrm{~N}$.

\begin{tabular}{|l|c|c|}
\hline Sample & Fixation PR-LCP $(\mathrm{mm})$ & Fixation A-LCP $(\mathrm{mm})$ \\
\hline 1 & 0.88 & 1.92 \\
\hline 2 & 0.35 & 0.80 \\
\hline 3 & 0.49 & 0.86 \\
\hline 4 & 1.72 & 1.81 \\
\hline 5 & 0.38 & 1.07 \\
\hline
\end{tabular}

Table 2. Size of mutual displacement of the proximal and distal bone fragment (collapse of the line of the fracture) in $\mathrm{mm}$ $(p=0.02)$ using the "plate and rod" fixation (PR-LCP) and LCP alone (A-LCP) under a force of $300 \mathrm{~N}$.

\begin{tabular}{|c|c|c|}
\hline Sample & Fixation PR-LCP $(\mathrm{mm})$ & Fixation A-LCP $(\mathrm{mm})$ \\
\hline 1 & 1.46 & 2.68 \\
\hline 2 & 0.49 & 1.28 \\
\hline 3 & 0.62 & 1.35 \\
\hline 4 & 1.87 & 2.35 \\
\hline 5 & 0.75 & 1.57 \\
\hline
\end{tabular}
bone fragment (collapse of the line of the fracture) in $\mathrm{mm}$ $(p=0.02)$ using the "plate and rod" fixation (PR-LCP) and LCP alone (A-LCP) under a force of $500 \mathrm{~N}$.

\begin{tabular}{|l|c|c|}
\hline Sample & Fixation PR-LCP $(\mathrm{mm})$ & Fixation A-LCP $(\mathrm{mm})$ \\
\hline 1 & 2.78 & 5.01 \\
\hline 2 & 0.79 & 2.70 \\
\hline 3 & 0.87 & 2.71 \\
\hline 4 & 2.81 & 3.67 \\
\hline 5 & 1.68 & 2.93 \\
\hline
\end{tabular}

Table 3. Size of mutual displacement of the proximal and distal of curves of the recording of the displacement of fragments with the $4.5 \mathrm{~mm}$ LCP in combination with the "plate and rod" technique and with only $4.5 \mathrm{~mm} \mathrm{LCP}$ are given in Figs 3 to 7 .

\section{Discussion}

Non-reducible fractures pose frequent problems both in veterinary and human medical science. The impossibility to reconstruct the original bone column (comminuted fracture) and fixation of the fracture by buttress (bridging) osteosynthesis means that all the forces have to be transmitted via the implants. Compared to the situation when the bone trans cortex has no defect, here the implant is much more strained (applied to the cis cortex) for several reasons: 1) decrease in the cross-sectional area of the bone-implant construct; 2) greater bending moment as a result of enlarged shoulder; and 3) decrease in the moment of inertia (Hulse et al. 1997). If the bone column is completely reconstructed the neutral axis lies in the medullar cavity, but if the defect is in the opposite cortex the neutral axis shifts closer to or directly into the bone disk and that is the cause of enlargement of the length of the shoulder of the bending moment. The ability to resist bending forces is considerably reduced in a case of defect of the trans-cortex, and this reduces the area moment of inertia (Hulse et al. 1997).

The combination of an intramedullary pin and bone plate in the case of fixation of comminuted fractures offers a number of mechanical and biological advantages. Mechanically the intramedullary pin acts as a replacement of the transcortical defect. The bone-implant construct is then more resistant to bending (Hulse et al. 1997). In our study 


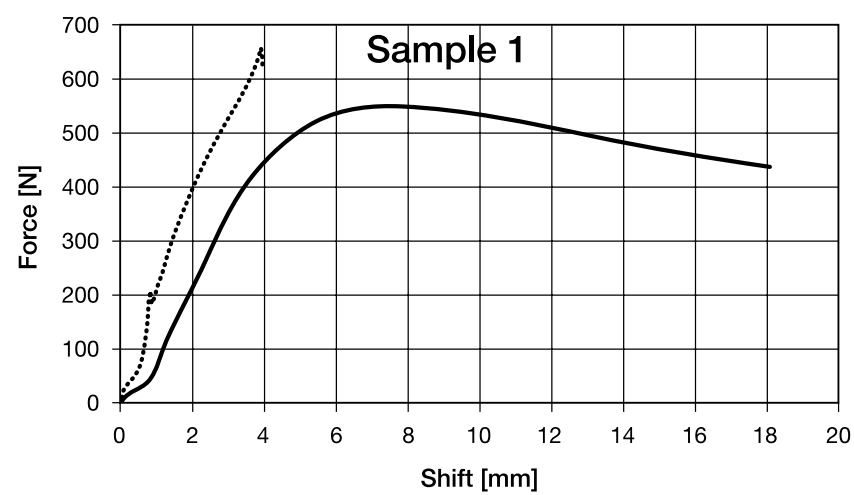

Fig. 3. Effect of the size of the acting force on the length of the mutual displacement of the proximal and distal bone fragment (collapse of the line of the fracture) using the "plate and rod" fixation (PR-LCP) (dotted line) and LCP alone (A-LCP) (full line) - femur 1.

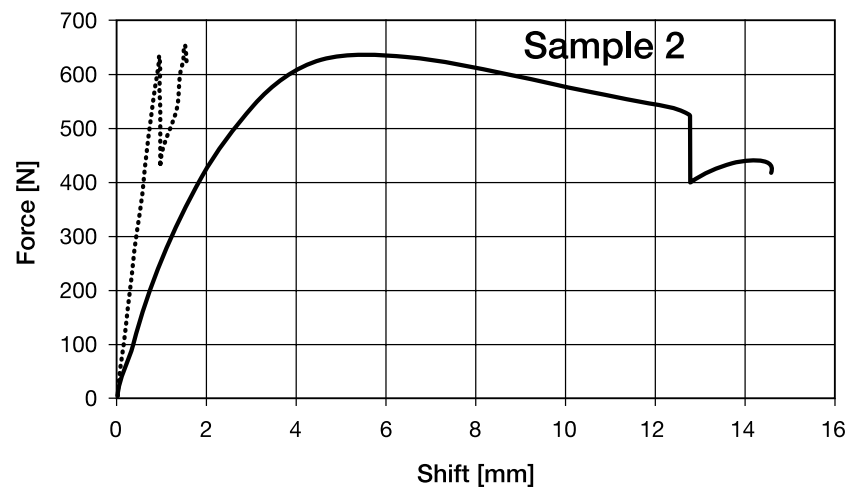

Fig. 4. Effect of the size of the acting force on the length of the mutual displacement of the proximal and distal bone fragment (collapse of the line of the fracture) using the "plate and rod" fixation (PR-LCP) (dotted line) and LCP alone (A-LCP) (full line) - femur 2.

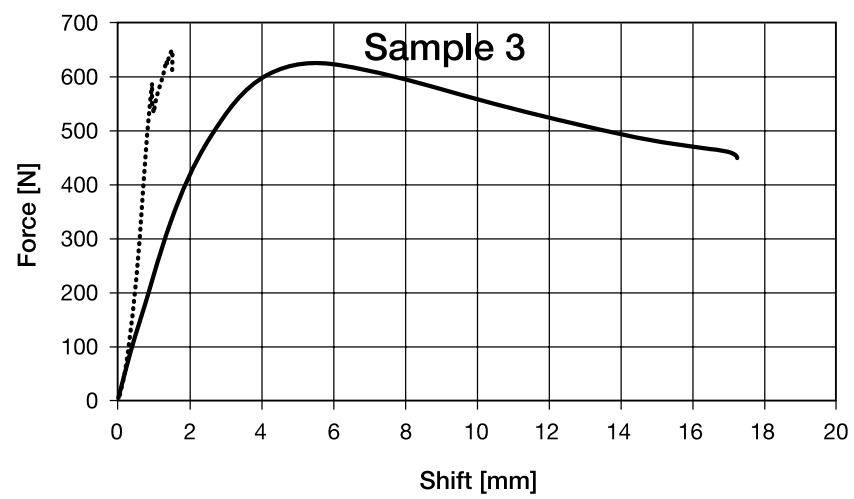

Fig. 5. Effect of the size of the acting force on the length of the mutual displacement of the proximal and distal bone fragment (collapse of the line of the fracture) using the "plate and rod" fixation (PR-LCP) (dotted line) and LCP alone (A-LCP) (full line) - femur 3. 


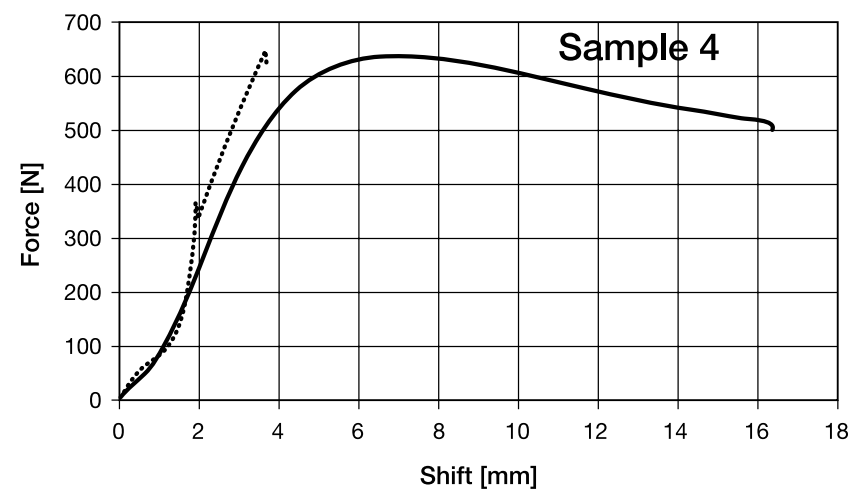

Fig. 6. Effect of the size of the acting force on the length of the mutual displacement of the proximal and distal bone fragment (collapse of the line of the fracture) using the "plate and rod" fixation (PR-LCP) (dotted line) and LCP alone (A-LCP) (full line) - femur 4.

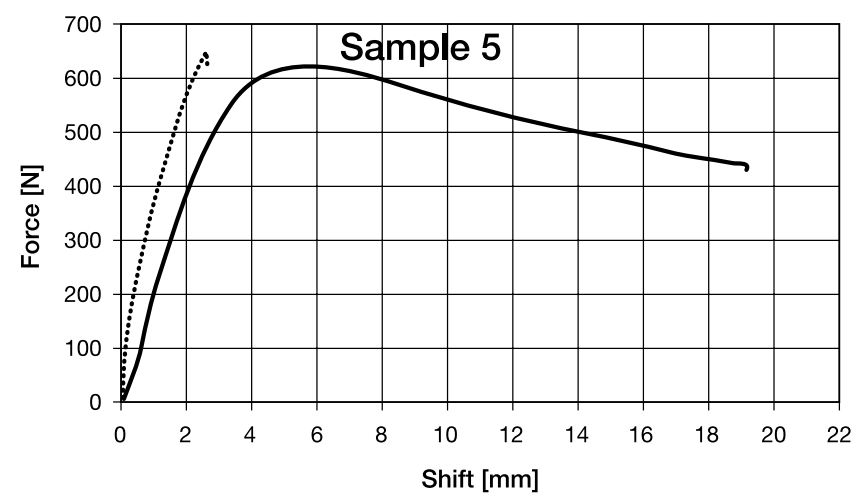

Fig. 7. Effect of the size of the acting force on the length of the mutual displacement of the proximal and distal bone fragment (collapse of the line of the fracture) using the "plate and rod" fixation (PR-LCP) (dotted line) and LCP alone (A-LCP) (full line) - femur 5.

the resistance of the LCP plate in combination with the pin (PR-LCP) to the action of all chosen degrees of acting forces was significantly greater than fixation with only LCP (A-LCP) (Tables 1, 2 and 3).

The hitherto conducted studies on the application of the "plate and rod" technique were not focused on fixation by flexible buttress osteosynthesis which uses the locking compression plate (LCP). Earlier clinical studies confirmed the suitability of the "plate and rod" fixation in dogs and cats using classical (DCP) plates. In these studies most of the recorded complications were connected with the migration of the pin and following irritation of the surrounding soft tissues (Reems et al. 2003). Under the effect of bending forces the pin tends to move in the bone (Hulse et al. 1997). The cause of migration of the pin is that the pin is not fixed firmly in the medullar cavity and that keeping it in the optimal position in which it was introduced is dependent only on the friction forces between the pin and the cancellous bone (Hulse et al. 1997). We monitored this phenomenon in our study too and in the graphic presentation of the course of the test it is evident in the form of a sharp decline in the force affecting the bone-implant construct, particularly in Fig. 3 (effect of a force of $200 \mathrm{~N}$ ) and Fig. 6 (effect of a force of $350 \mathrm{~N}$ ). The decline in the measured 
degree of the force was caused by displacement of the pin in the medullar cavity up to the stage of its contact with the bone compact, or with the fixture. It holds true that the greater the friction between the pin and the cancellous bone, the more effective the entire fixation system (Hulse et al. 1997).

The study conducted by Hulse et al. (2000) showed that the degree of strain on the bone plate was inversely related to the diameter of the intramedullary pin, or percentage of the diameter of the medullar cavity which the pin fills up. On the basis of this study the optimal degree of filling up the medullar cavity with a pin ranges between 35 and $40 \%$. Reems et al. (2003) recommended filling up $35-50 \%$ of the diameter of the medullary canal with the pin. In our case the pin thickness equalled to $30 \%$ of the diameter of the medullar cavity in order to be able to insert all screws bi-cortically and thus increase the strength of the fixation.

Opinions on the number of pins necessary for fixation with a plate in the "plate and rod" construct may differ (Reems et al. 2003). In their study, Hulse et al. (2000) deem necessary to insert at least 3 mono-cortical and 1 bi-cortical screws both into the proximal and distal bone fragment. In contrast, Reems et al. (2003) stated as sufficient 1 bi-cortical and 2 mono-cortical screws in each of the main bone fragments (proximal and distal). It is necessary to emphasise that in both studies DCP plates were used in the "plate and rod" construct. In our study we used the LCP plate fixed to the bone with two locking screws in the proximal fragment and two locking screws in the distal fragment of the femur, and that all the screws were inserted bi-cortically. During our mechanical tests of the resistance of the bone-implant construct to bending forces, an extraction, breaking or loosening of the screw did not occur even in one case.

In clinical practice another "biological" advantage of using the plate and rod fixation over the use of the plate separately is the possibility of removing the intramedullary pin at the time of formation of the bone callus and in this way enabling a greater strain on the fracture leading to an effective stimulation of healing (O'Sullivan et al. 1989).

Fixation of the segmental defect of the femur of miniature pigs using flexible bridging osteosynthesis with a five-hole $4.5 \mathrm{~mm}$ titanium LCP in combination with a $3 \mathrm{~mm}$ intramedullary Steinmann pin ("plate and rod" construct) (PR-LCP) in ex vivo mechanical tests is more resistant to the effect of bending forces than stabilisation with a $4.5 \mathrm{~mm} \mathrm{LCP}$ (A-LCP) alone. The "plate and rod" combination appears to be more suitable for the fixation of segmental lesions of the femur diaphysis where we can assume considerable strain of the osteosynthesis by bending forces. Results of the present study will enable to reduce any undesirable failure of the implants in time-consuming and costly in vivo transplantation experiments focused on bone healing as a part of further solutions of research project NPV II 2B06130.

\section{Srovnání odolnosti proti působení sil ohybu 4,5 LCP v konstrukci plate and rod a samotné 4,5 LCP použitých k fixaci segmentálních defektů femuru u miniaturních prasat}

Studie se zabývá mechanickými vlastnostmi flexibilní pilírové osteosyntézy z pohledu odolnosti konstrukce kost-implantát na působení sil ohybu při fixaci 4,5 mm titanovou LCP v kombinaci s 3 mm intramedulárním hřebem (konstrukce,,plate and rod“) (PR-LCP) v porovnání s fixací samotnou 4,5 mm titanovou LCP (A-LCP) na ex vivo modelu segmentální ostektomie femuru u miniaturních prasat.

Fixace technikou ,plate and rod“(PR-LCP) je statisticky významně $(p<0,05)$ odolnější proti působení sil ohybu $(200 \mathrm{~N}, 300 \mathrm{~N}$ a $500 \mathrm{~N})$, než samotná LCP (A-LCP).

Stabilizace experimentálních segmentálních lézí diafýzy femuru miniaturních prasat flexibilní pilírovou osteosyntézou 4,5 mm LCP v kombinaci „,plate and rod“ se jeví jako vhod- 
ná fixace nereponovatelných fraktur, u nichž lze předpokládat značné namáhání použitých implantátů ohybovými silami. Výsledky studie budou využity $\mathrm{v}$ in vivo experimentech zabývajících se hojením kostních defektů u miniaturních prasat transplantací mezenchymových kmenových buněk v kombinaci s biokompatibilními nosiči.

\section{Acknowledgements}

This work was supported by the by the Ministry of Education, Youth and Sports of the Czech Republic (Research Project NPV II 2B06130) and grant agency IGA VFU Brno (Project 259/2009/FVL).

\section{References}

Crha M, Nečas A, Srnec R, Janovec J, Stehlík L, Raušer P, Urbanová L, Plánka L, Jančář J, Amler J 2009: Mesenchymal stem cells in bone tissue regeneration and application to bone healing. Acta Vet Brno 78: 635-645 Gautier E, Sommer C 2003: Guidelines for the clinical application of the LCP. Injury 34: S-B63-S-B76

Hulse D, Ferry K, Fawcett A, Gentry D, Hyman W, Geller S, Slater M 2000: Effect of intramedullary pin size on reducing bone plate strain. Vet Comp Orthop Traumatol 13: 185-190

Hulse D, Hyman W, Nori M, Slater M 1997: Reduction in plate strain by addition of an intramedullary pin. Vet Surg 26: 451-459

Hulse D, Kerwin S, Mertens D 2005: Fractures of the femoral diaphysis in AO principles of fracture management in the dog and cat. AO Publishing, Switzerland, pp. 287-295

Jančář J, Slovíková A, Amler E, Krupa P, Kecová H, Plánka L, Gál P, Nečas A 2007: Mechanical response of porous scaffolds for cartilage engineering. Physiol Res 56: S17-S25

Jančář J, Vojtová L, Nečas A, Srnec R, Urbanová L, Crha M 2009: Stability of collagen scaffold implants for animals with iatrogenic articular cartilage defects. Acta Vet Brno 78: 643-648

Koch D 2005: Screws and plates. In: AO principles of fracture management in the dog and cat. AO Publishing, Switzerland, pp. 26-50

Koláčná L, Bakešová J, Varga F, Košt’áková E, Plánka L, Nečas A, Lukáš D, Amler E, Pelouch V 2007: Biochemical and biophysical aspects of collagen nanostructure in the extracellular matrix. Physiol Res 56: S51-S60

Krupa P, Kršek P, Javorník M, Dostál O, Srnec R, Usvald D, Proks P, Kecová H, Amler E, Jančář J, Gál P, Plánka L, Nečas A 2007: Use of 3D geometry modelling of osteochondrosis-like iatrogenic lesions as a template for press-and-fit scaffold seeded with mesenchymal stem cells. Physiol Res 56: S107-S114

Lambiris E, Panagopoulos A, Zouboulis P, Sourgiadaki E 2007: Current concepts: aseptic nonunion of femoral shaft diaphysis. Eur J Trauma Emerg Surg 2: 120-134

Míčková A, Tománková K, Kolářová H, Bajgar R, Kolář P, Šunka P, Plencner M, Jakubová R, Beneš J, Koláčná L, Plánka L, Nečas A, Amler E 2008: Ultrasonic shock-wave as a control mechanism for liposome drug delivery system for possible use in scaffold implanted to animals with iatrogenic articular cartilage defects. Acta Vet Brno 77: 285-296

Nečas A, Plánka L, Srnec R, Raušer P, Urbanová L, Lorenzová J, Crha M, Jančář J, Gál P 2008: Biomaterials and stem cells in the treatment of articular cartilage, meniscal, physeal, bone, ligamentous and tendineous defects. Acta Vet Brno 77: 277-284

Nečas A, Proks P, Urbanová L, Srnec R, Stehlík L, Crha M, Raušer P, Plánka L, Amler E, Vojtová L, Jančář J 2010a: Radiographic assessment of implant failures of titanium 3.5 LCP vs. 4.5 LCP used for flexible bridging osteosynthesis of large segmental femoral diaphyseal defects in a miniature pig model. Acta Vet Brno 79: 599-606

Nečas A, Proks P, Srnec R, Stehlík L, Urbanová L, Crha M, Raušer P, Janovec J, Dvořák M 2009: Současné trendy v chirurgické léčbě segmentálních fraktur (MIPO, LCP, biomateriály). In Zborník príspevkov z odbornej konferencie „Škola, veda, prax II.“, Košice, Slovenská republika: UVL Košice, pp. 123-127

Nečas A, Proks P, Urbanová L, Srnec R, Stehlík L, Crha M, Raušer P, Plánka L, Amler E, Vojtová L, Jančář J 2010b: Healing of large segmental bone defect after implantation of autogenous cancellous bone graft in comparison with hydroxyapatite and $0.5 \%$ collagen scaffold in combination with mesenchymal stem cells. Acta Vet Brno 79: 607-612

Nečas A, Plánka L, Srnec R, Crha M, Hlučilová J, Klíma J, Starý D, Křen L, Amler E, Vojtová L, Jančář J, Gál P 2010: Quality of newly formed cartilaginous tissue in defects of articular surface after transplantation of mesenchymal stem cells in a composite scaffold based on collagen I with chitosan micro- and nanofibres. Phys Res 59: 605-614

Nečas A, Urbanová L, Srnec R 2007: Principy použití LCP plotének. In: Nečas A, Beale BS, Hulse DA, Srnec R a kol.: Osteotomie a nové trendy v léčbě nemocí kostí a kloubů. VFU Brno, pp. 19-22

Piermattei DL, Flo GL 1997: Brinker, Piermattei, and Flo's Handbook of Small Animal Orthopedics and Fracture Repair. $3^{\text {rd }}$ ed. Philadelphia: WB Saunders, pp. 24-146

Plánka L, Gál P, Kecová H, Klíma J, Hlučilová J, Filová E, Amler E, Krupa P, Křen L, Srnec R, Urbanová L, Lorenzová J, Nečas A 2008: Allogeneic and autogenous transplantations of MSCs in treatment of the physeal bone bridge in rabbits. BMC Biotechnology 8: 70, doi:10.1186/1472-6750-8-70 
Plánka L, Nečas A, Gál P, Kecová H, Filová E, Křen L, Krupa P 2007: Prevention of bone bridge formation using transplantation of the autogenous mesenchymal stem cells to physeal defects: an experimental study in rabbits. Acta Vet Brno 76: 253-263

Plánka L, Nečas A, Srnec R, Raušer P, Starý D, Jančář J, Amler E, Filová E, Hlučilová J, Křen L, Gál P 2009a: Use of allogenic stem cells for the prevention of bone bridge formation in miniature pigs. Phys Res 58: 885-893

Plánka L, Starý D, Hlučilová J, Klíma J, Jančář J, Křen L, Lorenzová J, Urbanová L, Crha M, Srnec R, Dvořák M, Gál P, Nečas A 2009b: Comparison of preventive and therapeutic transplantations of allogeneic mesenchymal stem cells in healing of the distal femoral growth plate cartilage defects in miniature pigs. Acta Vet Brno 78: $293-302$

Reems MR, Beale BS, Hulse DA 2003; Use of a plate-rod construct and principles of biological osteosynthesis for repair of diaphyseal fractures in dogs and cats:47 cases (1994-2001). JAVMA, 223: 330-335

Stoffel K, Dieter U, Stachowiak G, Gächter A, Kuster MS 2003: Biomechanical testing of the LCP - how can stability in locked internal fixators be controlled? Injury Int J Care Injured 34: S-B11-S-B19

Stoffel K, Klaue K, Perren SM 2000: Functional load of plates in fracture fixation in vivo and its correlate in bone healing. Injury Int J Care Injured 31: S-B37-S-B50

O'Sullivan ME, Chao EYS, Kelly PJ 1989: The effects of fixation on fracture healing. J Bone Joint Surg 71: 306-310

Urbanová L, Srnec R, Proks P, Stehlík L, Nečas A 2010: Testování pevnosti fixace segmentálního defektu femuru samotnou 4,5 LCP a v konstrukci plate and rod. (Testing of stiffness of segmental femoral defect fixation using 4.5 LCP alone versus 4.5 LCP in plate-rod construct). In: Sborník XII. konference mladých vědeckých pracovníků s mezinárodní účastí, 2.6.2010, 217-219

Varga F, Držík M, Handl M, Chlpík J, Kos P, Filová E, Rampichová M, Nečas A, Trč T, Amler E 2007: Biomechanical characterization of cartilages by a novel approach of blunt impact testing. Physiol Res 56: 61-68

Wagner M. 2003: General principles for the clinical use of the LCP. Injury Int J Care Injured 34: B31-B42 
Urbanová L. et al.: Comparison ... pp. 613-620

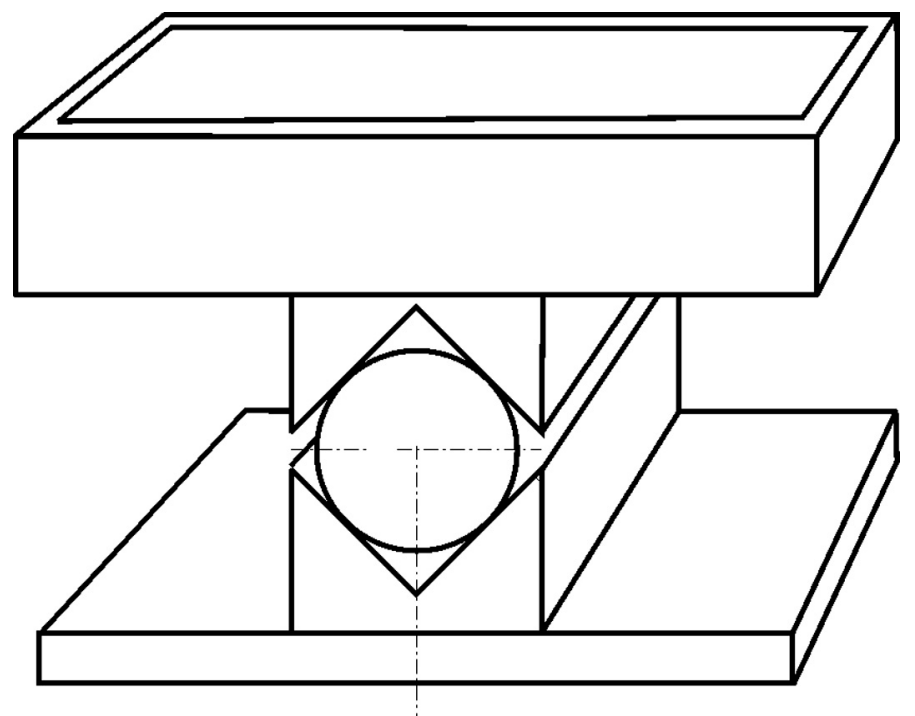

Fig. 1. Chart of the three-piece fixture. 
Plate IX

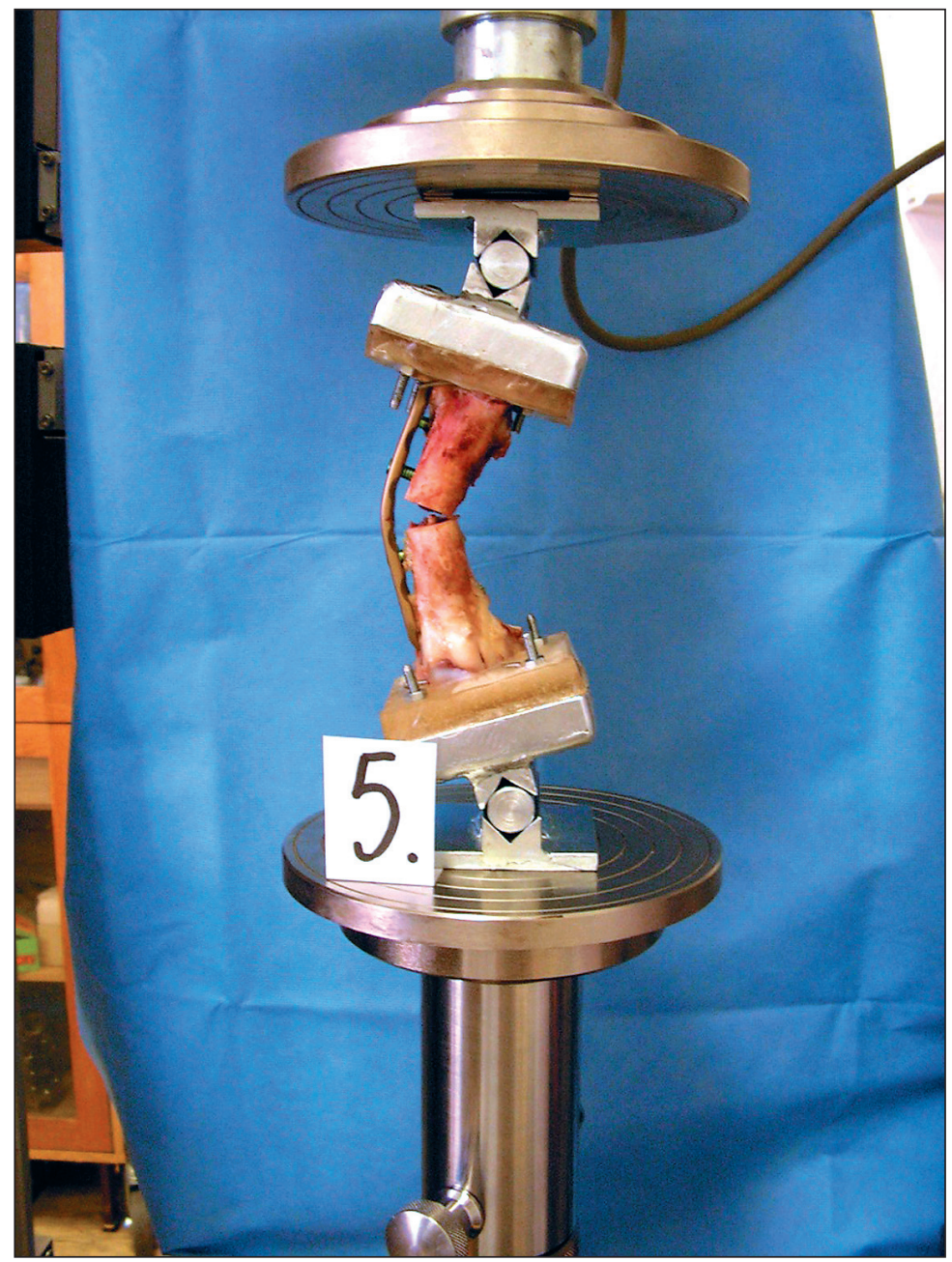

Fig. 2. Testing the $4.5 \mathrm{~mm} \mathrm{LCP} \mathrm{(A-LCP)} \mathrm{on} \mathrm{an} \mathrm{ex} \mathrm{vivo} \mathrm{model} \mathrm{of} \mathrm{segmental} \mathrm{ostectomy} \mathrm{of} \mathrm{the} \mathrm{femur}$ of a miniature pig on the ZWICK Z 020-TND experimental machine. 